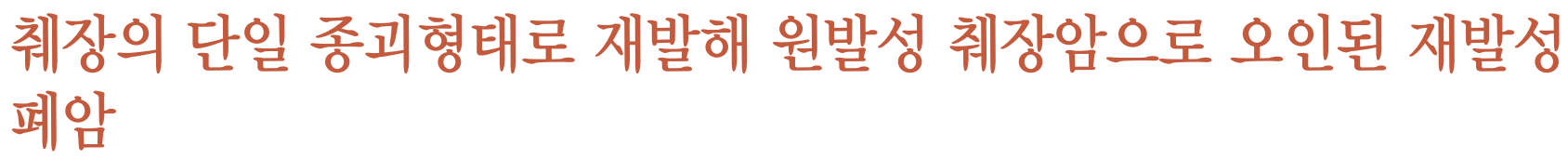

대구가톨릭대학교 의과대학 내과학교실

김지윤 · 이동욱 · 배상수 · 오재영 · 한지민 · 김호각

\title{
Lung Cancer Recurrence with Solitary Pancreatic Metastasis Mimick- ing Primary Pancreatic Cancer
}

\author{
Ji Yoon Kim, Dong Wook Lee, Sang Soo Bae, Jae Young Oh, Jimin Han, Ho Gak Kim \\ Department of Internal Medicine, Daegu Catholic University School of Medicine, Daegu, Korea
}

Pancreas metastasis of primary lung cancer is known to be very rare and if it occurs, most cases are disseminated malignant status and do not affect therapeutic plan. We experienced a case of lung cancer recurrence with solitary pancreas metastasis and mimicks primary pancreatic cancer. A 54-year old man was admitted to the hospital for further evaluation of pancreatic solitary mass. He underwent left pneumonectomy and adjuvant chemotherapy for treatment of lung adenocarcinoma 3 years ago. After surgical treatment, the lesion was confirmed metastatic adenocarcinoma of lung cancer origin. He was discharged and followed up for 24 months without recurrence.

Korean J Pancreas Biliary Tract 2018;23(4):172-176

Keywords: Lung cancer, Pancreas metastasis, Pancreatic cancer

\author{
Received May 10, 2018 \\ Revised Jun. 26, 2018 \\ Accepted Jul. 3,2018
}

Corresponding author : Dong Wook Lee Department of Internal Medicine, Daegu Catholic University Medical Center, 33 Duryugongwon-ro

17-gil, Nam-gu, Daegu 42472, Korea

Tel. +82-53-650-4217 Fax. +82-53-656-3281

E-mail; storm5333@naver.com

ORCID: https://orcid.org/0000-0002-1029-9064

\section{INTRODUCTION}

Primary lung cancer frequently metastasizes to distant organs such as liver, adrenal gland and bone, but metastasis to pancreas is known to be rare. ${ }^{1}$ In addition, most cases of pancreas metastasis are those of disseminated malignant disease and do not affect clinical decision. ${ }^{2}$ However, if the metastasis occurs in the form of a solitary mass in the pancreas, or recurs, it is important to determine whether the lesion is primary pancreatic cancer or solitary pancreatic metastasis before deciding on a treatment regimen. We report a case of lung cancer recurrence in the form of solitary pancreatic mass in a patient on follow-up after surgical treatment of left lung cancer 3 years ago with adjuvant chemotherapy, along with literature review.

\section{CASE}

A 54-year-old male patient presented for further evaluation of a solitary mass in the body of the pancreas. Patient 
underwent left pneumonectomy for a left lung mass found 3 years ago, which was found to be adenocarcinoma (T2N2M0, stage IIIA according to AJCC 7th edition).

For the prevention of recurrence, patient underwent adjuvant chemotherapy for 2 months with paclitaxel/cisplatin regimen. Follow-up computed tomography (CT) showed a new mass in the right adrenal gland. This lesion was considered recurrent lung cancer, and the chemotherapy regimen was changed to pemetrexed.

Follow-up CT at 4 months after the administration of pemetrexed no longer showed the right adrenal mass. Patient underwent 8 cycles of chemotherapy with pemetrexed, after which he refused further chemotherapy. Patient has been on follow-up since.

Thirty-four months after the left pneumonectomy and 24 months after the discontinuation of pemetrexed, a follow-up CT showed a solitary mass in the body of the pancreas that was previously not found (Fig. 1). On CT, the mass was welldelineated, $2.5 \mathrm{~cm}$ in size, and showed hypoattenuating pattern during the arterial, pancreatic, and delayed phases. The right adrenal mass that had previously disappeared was still not seen. Patient's blood tests were unremarkable, with results as follow: white blood cell 9,000/ $\mathrm{mm}^{3}$, hemoglobin $13.2 \mathrm{~g} / \mathrm{dL}$, platelet $359,000 / \mathrm{mm}^{3}$, aspartate aminotransferase $15 \mathrm{U} / \mathrm{L}$, alanine aminotransferase $11 \mathrm{U} / \mathrm{L}$, alkaline phosphatase $53 \mathrm{U} / \mathrm{L}$, r-glutamyl transpeptidase $30 \mathrm{U} / \mathrm{L}$, blood urea nitrogen $13.1 \mathrm{mg} / \mathrm{dL}$, Creatinine $0.9 \mathrm{mg} / \mathrm{dL}$, Amylase $119 \mathrm{U} / \mathrm{L}$, Lipase $39 \mathrm{U} / \mathrm{L}$, carcinoembryonic antigen $1.45 \mathrm{ng} / \mathrm{mL}$, carbohydrate antigen 19-96 U/mL.

Positron emission tomography-CT (PET-CT) was per-

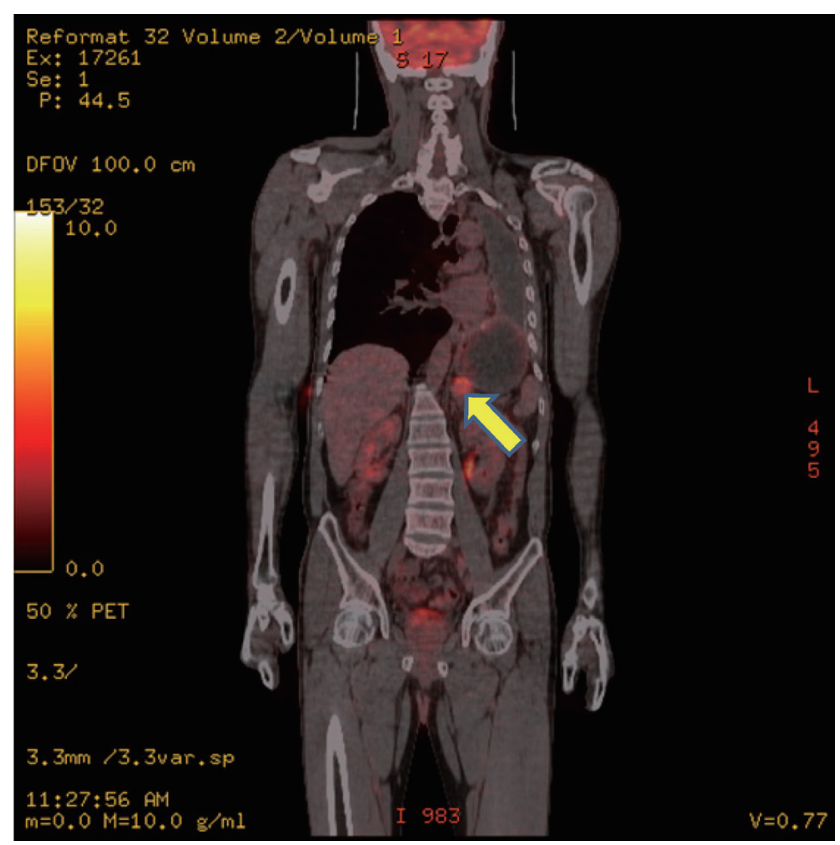

Fig. 2. Positron emission tomography computed tomography revealed hypermetabolic mass lesion (arrow) in pancreas body.
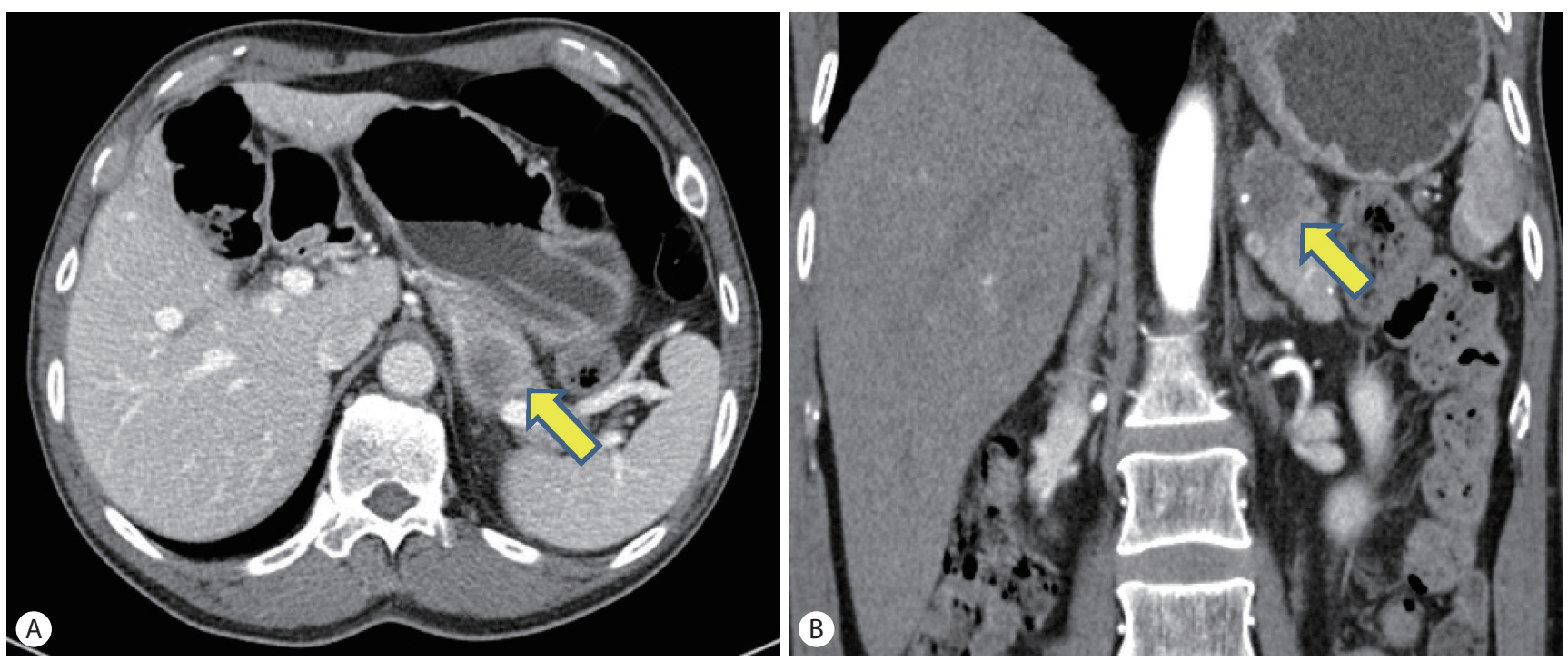

Fig. 1. Computed tomography of abdomen revealed a $2.5 \mathrm{~cm}$ sized hypoattenuating mass (arrows) in pancreas body. (A) Cross section. (B) Coronal section. 
formed, and the mass seen on CT was found to be a hypermetabolic mass with standard uptake value (SUV) of 4.75 and considered to have a high probability of malignancy (Fig. 2). There was no evidence of recurrence around the site of previous left pneumonectomy as well as other organs.

Endoscopic ultrasonography (EUS) was performed, which showed a $2.8 \mathrm{~cm}$ mass in the pancreatic body (Fig. 3). The mass was relatively homogeneous, isoechoic with hypoechoic margins, and well-delineated. The mass was invading the splenic vein, and there were no enlarged lymph nodes ob-

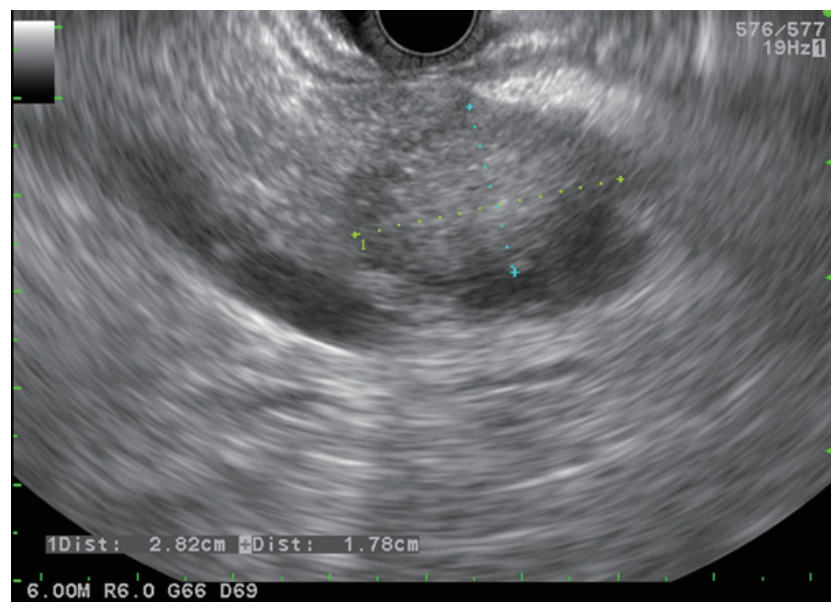

Fig. 3. Endoscopic ultrasound showed relatively homogeneous, isoechoic mass lesion surrounded with hypoechoic margins at pancreas body. served around the pancreas. EUS guided fine needle aspiration (FNA) was subsequently performed. Cytology reports showed findings consistent with adenocarcinoma, but whether the mass was metastatic cancer or primary pancreatic cancer could not be determined.

Patient was transferred to the department of surgery for surgical management and underwent distal pancreatectomy with splenectomy. Postoperative histologic evaluation confirmed adenocarcinoma, with positive finding of thyroid transcription factor (Fig. 4). Histology findings were consistent with post-pneumonectomy histology results from 3 years ago, confirming the diagnosis of metastatic adenocarcinoma of lung cancer origin. There were no tumor cells observed in the resection margin or the intraoperatively dissected regional lymph nodes, and no lymphovascular invasion was observed. Patient was discharge without complication and is being followed up on an outpatient basis for 24 months without recurrence.

\section{DISCUSSION}

Around 3\% of solid pancreatic lesions are known to be pancreatic metastasis, with the most common primary origin being renal cell carcinoma. Pancreatic metastasis of lung cancer depends on the histological subtype: small cell carcinoma is
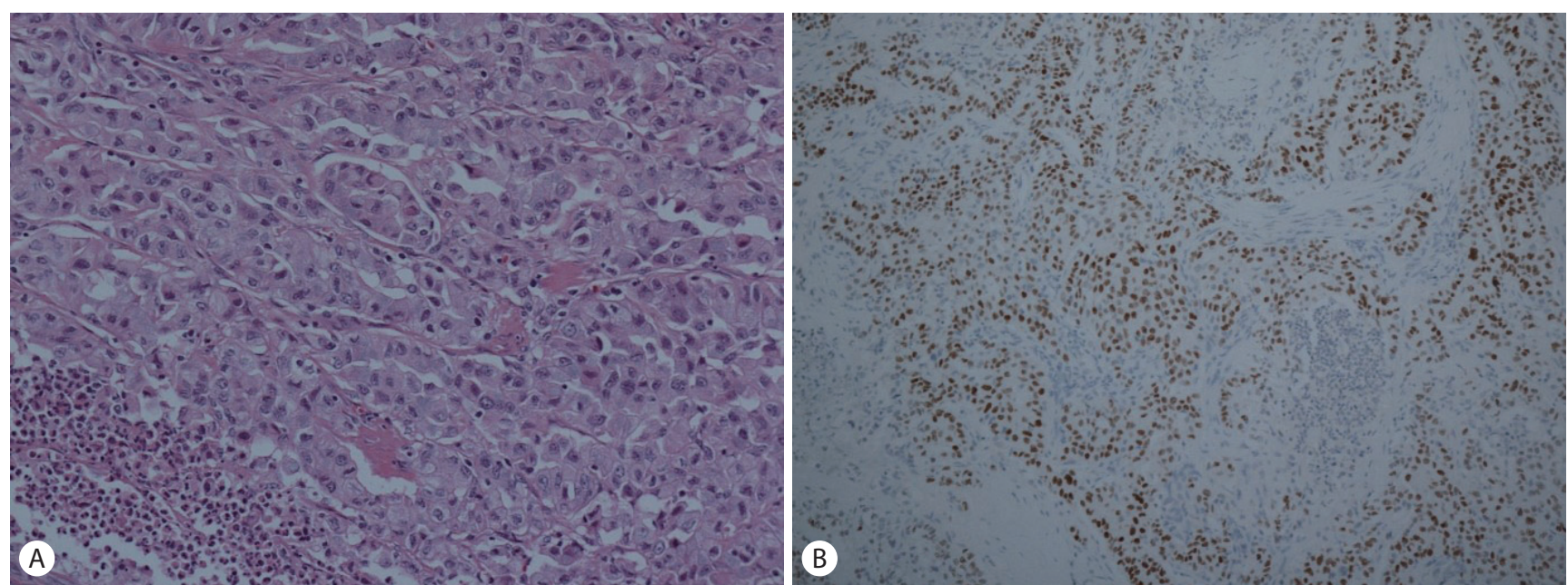

Fig. 4. Pathologic findings. (A) Tumor cells are arranged in solid nests or pseudoglandular pattern with thin fibrous stroma. Individual cells have plump mucinous cytoplasm and thick cytoplasmic membrane (H\&E stain, $x 200$ ). (B) Tumor cells show strong nuclear staining for thyroid transcription factor (TTF) -1 (Immunohistochemistry, x 100). 
the most common at 10\%, and adenocarcinoma, as in the case of our patient, is known to be around $2.4 \%$. In Korean studies, since a case of small cell lung cancer metastasizes to pancreas was reported in $1990,{ }^{3}$ a few cases of pancreatic metastasis of small cell lung cancer has been reported in case report form. In 2000, 2007 and 2010, several cases of nonsmall cell lung cancer metastasizes to pancreas were reported, but there was no case described as adenocarcinoma like our case. $^{4-6}$

Patients with metastatic pancreas tumor may be asymptomatic or experience symptoms of abdominal pain, weight loss, jaundice, or hyperglycemia. ${ }^{2,7}$ In a recent study of single institution in Korea, 58\% of patients with metastasis to pancreas were found at follow-up imaging without any symptoms, and $42 \%$ were found with related symptoms. ${ }^{6}$ Our patient was asymptomatic and had unremarkable blood test results except for mild elevation of amylase. There have been reported cases of accompanying acute pancreatitis, but all were small cell carcinoma in origin. ${ }^{8}$ The elevation of amylase seen in our patient was less than 3 times the upper limit of normal, and no abdominal pain was reported, hence acute pancreatitis was ruled out.

Characteristic radiological findings for pancreas metastatic lesion are not yet known, but incidental finding on CT is known to be the most common. ${ }^{1}$ In our patient, the pancreatic mass was found on abdominal CT performed to evaluate the recurrence of adrenal mass. Pancreatic metastatic lesions are more commonly found as single than multiple and characterized by clear border and no invasion of surrounding tissues or blood vessels. ${ }^{4}$ However, CT findings were not sufficient to conclude that this lesion was metastatic. Discovery of lung cancer metastasis on PET-CT that was previously missed on CT is known to occur in about $10 \%$ of cases, ${ }^{9}$ but the characteristic findings or the diagnostic rate of pancreatic metastasis of lung cancer is not yet known. In our case as well, we were unable to confirm whether the pancreatic mass was primary pancreatic cancer or pancreatic metastasis on CT alone.

On EUS evaluation, pancreas metastatic lesion is known to show relatively well-define borders compared to primary pancreatic cancer, ${ }^{10}$ but there have been studies that state that it is difficult to distinguish between metastatic lesion and primary pancreatic cancer. Therefore, pathological confirmation is the recommended diagnostic tool in this case. ${ }^{11}$ In our case, a well-defined mass was found in the pancreas, and EUS-FNA was performed for pathologic confirmation.

As is widely known, pathological diagnosis via EUS can be made with FNA or fine needle biopsy (FNB). Cytomorphology alone is insufficient to distinguish between primary pancreatic cancer and metastatic cancer, but multiple immunohistochemical stain such as thyroid transcription factor on tissue specimen allows for this distinction, hence FNB is usually preferred. ${ }^{10,11}$ However, in our case, there were no enlarged lymph nodes observed around the pancreas nor vascular invasion other than splenic vein invasion. Hence, only FNA was performed, but sufficient core tissue was not obtained. Since surgical management of this patient was deemed plausible.

If the origin of pancreatic metastasis is renal cell carcinoma, prognosis is reported to be quite good with overall survival of 12 months or longer, but lung cancer metastasis to the pancreas is known to have poor prognosis. ${ }^{12}$ However, our patient is being followed up for 24 months after surgical management without recurrence. This is thought to be due to the fact that the metastasis is limited to the pancreas and that this lesion was resected with en-bloc \& $\mathrm{R} 0$ resection without surrounding lymph node invasion.

Treatment of metastatic tumors of the pancreas has not been established. But, several small series have documented that a low postoperative mortality with excellent long-term survival can be achieved for resection of focal pancreatic metastases. ${ }^{11}$ Therefore, pancreatic metastases have to be kept in mind when a patient with pancreatic mass has a history of other malignancy, even if treated several years before, in the absence of widely metastatic disease, aggressive surgical approach may offer the chance of long-term survival. ${ }^{12}$

Pancreatic metastasis of primary lung cancer is known to be rare. We report a case of lung cancer recurrence in the form of solitary pancreatic mass in a 54-year-old male patient on follow-up after surgical treatment of left lung cancer with 
adjuvant chemotherapy, which was successfully treated with surgery, along with literature review.

\section{요 약}

저자들은 3년 전 폐선암으로 수술과 수술 후 보조항암요법을 시행한 뒤 경과관찰 중인 환자에게 췌장내 단일 고형 종괴가 발생한 것을 확인하고 수술적 치료를 시행하였다. 수술 후 조직검사 결과, 췌장의 단일 고형 종괴는 폐선암의 재발인 것으로 확진되었기에 문헌고찰과 함께 보고하는 바이다.

국문 색인: 폐암, 췌장 전이, 췌장암

\section{Conflicts of Interest}

The authors have no conflicts to disclose.

\section{REFERENCES}

1. García Vidal C, Carrillo E, Barreiro B. Solitary metastasis to the pancreas in a patient with lung cancer. Arch Bronconeumol 2003;39:601.

2. Golbin JM, Kalra S, Midthun DE. Metastatic lung cancer to the pancreas. J Thorac Oncol 2006;1:360-361.
3. Cho YD, Cho JY, Lee MS. A case report of extrahepatic biliary obstruction caused by metastatic pancreatic small cell cancer. Korean J Gastroenterol 1990;22:1019-1026.

4. Lee SJ, Lee WJ, Lim HK, et al. Metastatic tumor of the pancreas: helical CT findings. J Korean Radiol Soc 2000;42:657-661.

5. Yoon WJ, Park JK, Lee SH, et al. Metastatic tumors of the pancreas. Korean J Med 2007;72:266-271.

6. Boo SJ, Kim MH, Kim YS, et al. Clinical characteristics of pancreatic metastases. Korean J Gastroenterol 2011;57:358-364.

7. Ardengh JC, Lopes CV, de Lima LF, et al. Diagnosis of pancreatic tumors by endoscopic ultrasound-guided fine-needle aspiration. World J Gastroenterol 2007;13:3112-3116.

8. Noseda A, Gangji D, Cremer M. Acute pancreatitis as presenting symptom and sole manifestation of small cell lung carcinoma. Dig Dis Sci 1987;32:327-331.

9. Lowe VJ, Naunheim KS. Current role of positron emission tomography in thoracic oncology. Thorax 1998;53:703-712.

10. Ishikawa T, Hirooka Y, Teman CJ, Goto H, Belletrutti PJ. An unusual case of pancreatic metastasis from squamous cell carcinoma of the lung diagnosed by EUS-guided fine needle biopsy. Case Rep Gastrointest Med 2017;2017:3212056.

11. DeWitt J, Jowell P, Leblanc J, et al. EUS-guided FNA of pancreatic metastases: a multicenter experience. Gastrointest Endosc 2005;61:689-696.

12. Sperti C, Pasquali C, Liessi G, Pinciroli L, Decet G, Pedrazzoli S. Pancreatic resection for metastatic tumors to the pancreas. J Surg Oncol 2003;83:161-166; discussion 166. 